\title{
The impact of the Sloping Land Conversion Program on rural area in China: a case study in Yulin District
}

\author{
Shunsuke Hori ${ }^{1}$ and Kazuko KoJIMA ${ }^{2)}$ \\ ${ }^{1}$ Kasugai Mill, Ojipaper CO.,Ltd, Japan \\ Graduate School of Humanities and Social Sciences. University of Tsukuba, Japan \\ Coresponding author: Tel: +81-568-85-2018/Fax: +81-568-85-2345, E-mail: shunsuke-hori@kasugai-m.ojipaper.co.jp
}

\begin{abstract}
In 1999, China started the Sloping Land Conversion Program (SLCP). Providing farmers with monetary and food subsidiaries, this program intends to green farmlands in areas which have suffered from desertification and over-cultivation on the slope. Its aim is notable in targeting both the restoration of ecology and the adjustment of the rural economic structure. Based on our field study at $Y$ village of Mizhi County of Shaanxi Province, this paper discussed the impacts of the SLCP upon rural life and regional economic growth. Our study reveals that the nonagricultural income had multiplied while the agricultural earning had rapidly decreased since the inception of the SLCP. This tendency underlines the program's effects of accelerating the transformation in the rural economic structure. As the region has experienced a rapid economic growth driven by mineral resources development, it has been enlarging the opportunities of employment sufficient to absorb the surplus of workforce in the rural area. This mechanism illustrates a close relationship between the SLCP and the regional economic growth.
\end{abstract}

\section{INTORODUCTION}

It is widely recognized that with the breathtaking pace of economic growth in the last 25 years China has become one of the world's largest importers of forest products. On the other hand, China's forest areas have constantly increased since the foundation of the People's Republic of China: jumping from 8.6 percent in 1949 to 18.2 percent in 2004 under the political system of the Chinese Communist Party. Moreover, we can see a significant change in China's forest policy from the middle of $20^{\text {th }}$ century to date. There is a greater need to cope with frequent droughts, floods and sand storms that are arguably attributable to deforestation. This alarming situation has led to a clear shift in China's forest policy. The policy's emphasis is put on protecting the existing forest resources and creating new forests through plantation on farmlands and devastated lands. The above shift has been evident particularly since the launch of the Six Major Forest Policy in 2001 typified by Natural Forest Conservation Policy (NFCP), Sloping Land Conversion Program (SLCP).

In 2003, 9.1 million ha of land was subject to efforts of plantation made by several agencies, ranging from governmental to private organizations. Ninety one percent of the plantation was implemented by the Six Major Forestry Projects, and 68 percent by the SLCP. In terms of investment, 83 percent of the national investment in forestry in 2003 was allocated to the Six Major Forest Projects and 55 percent to SLCP. Considering these statistical data, it is evident that the SLCP is the most influential program concerning China's forestry at present and is one of the largest land-conservation programs in the world (WWF, 2003).

In principle, SLCP is a project aiming at prohibiting cultivation on the slopes 25 degrees or more and converting them into forestlands or grasslands. Farmers who have converted part of their cultivated land into forestlands are eligible for compensations from the government in the form of cash and foods during 5-8 years of the period of contract.

Through the period of the People's Republic of China has been made numerous attempts to restore natural resources. Consequently, by these attempts including an afforestation campaign called "public mobilization" (Hirano, 2002) have succeeded to increase the area of forests adequately. But the campaign provoked a great controversy over the inefficiency of afforestation carried out by the Central Government. Although billions of seedlings have been planted, little attention has been paid to the care of planted trees. The Central Government 
officially admitted that only less than 30 percent of the trees that had been planted since 1949 remained in 1978 (Peoples' Daily, 1978). But these previous failures of "public mobilization" offer us a clue whether or not the sustainable implementation of SLCP. After the expiration of the 5-8 years subsidies period under the SLCP, farmers are forced to choose between living without cultivating SLCP land or farming it again. It is generally agreed among scholars that the sustainable implementation of SLCP depends on how the farmers can diversify their livelihood (Seki and Xiang, 2003; Xu et al. 2004).

Although a large number of studies have been conducted on Chinese politics and the economy, its little attention has been paid to Chinese forest management and forest policy has received little attention despite the rise of China's importance in the world forestry (Liu and Edmunds, 2003). Over the past few years, however, an increasing number of studies analyze not only Chinese forest management but also SLCP. Among them are several recent articles which argued that the development of SLCP has been influencing China's rural society and farmers to varying degrees (Zuo, 2002; Seki and Xiang, 2003; Grant, 2003; Xu et al. 2004). What is left uninvestigated, however, is to examine the process in which SLCP contributed to the diversification of the farmers' income and to illustrate the correlation between the effects of SLCP at rural and regional level of economic growth. The study is attempted to address the above question taking SLCP's impacts on rural society and the resultant transformation in farmers' livelihoods. The study also seeks to demonstrate the correlation between regional economic growth and the implementation of SLCP though the case study of a village in Shaanxi Province.

\section{METHODS}

We have conducted two types of field survey: both at regional level and at village level. The former approach was applied in Yulin City in Shaanxi Province and latter was carried out in Y Village in Mizhi County of Yulin City.

At the regional level, we analyzed documentations, especially statistical data. At the village level, we conducted structured interviews with officials of the Mizhi Forest Bureau, Village Committee staff and village households by using questionnaires. We also collected the socio-economical data of 27 households which were randomly extracted from 226 households and interviewed at Y village. We basically interviewed in principle, with the household heads. If they were not available, we interviewed their spouses. Our field survey was conducted from July and August 2004 in Y village, Mizhi County, Yulin City, Shaanxi Province. All photographs in this paper were taken by the authors in August unless noted.

This paper consists of four parts. First, we analyze the process of executing SLCP by focusing upon its area and investment and discuss a possible way of its

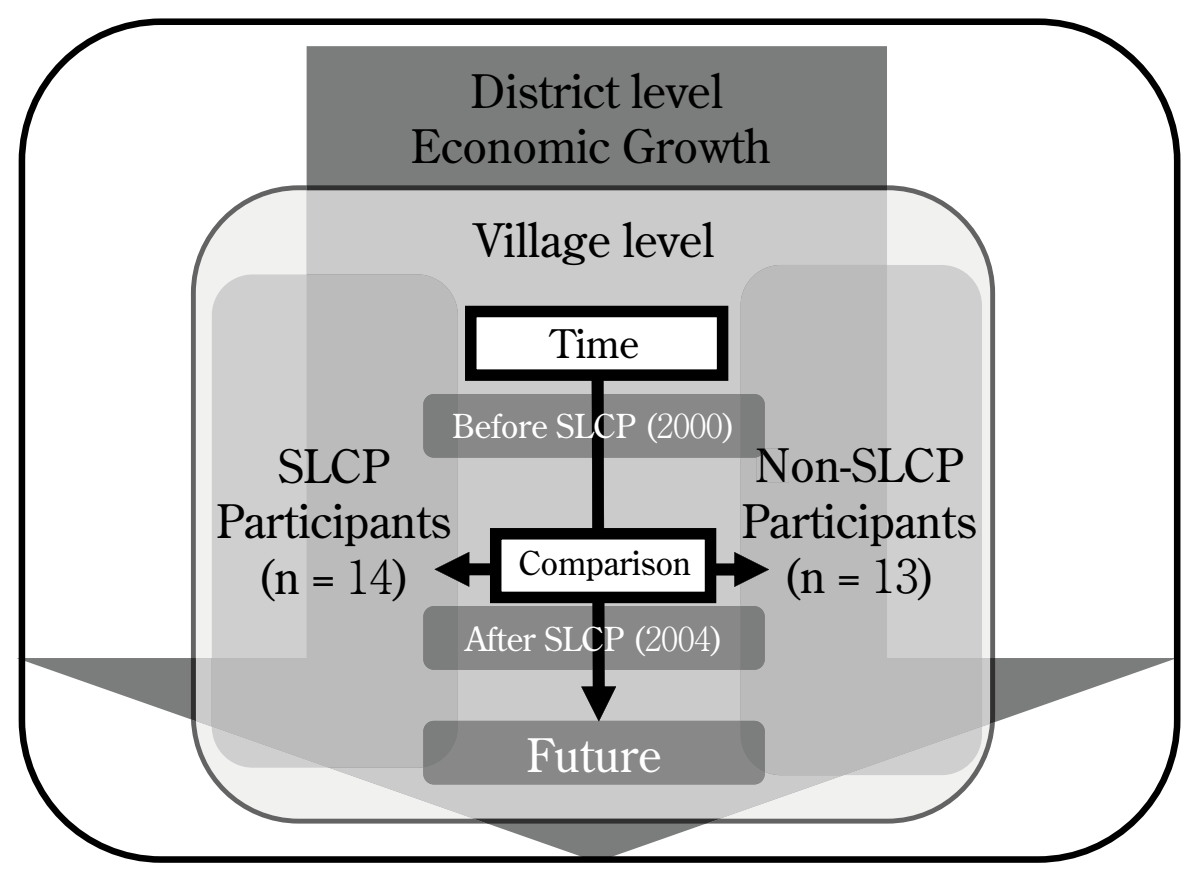

Fig. 1. Conceptual diagram of research in this study. 
sustainable implementation. Second, we illustrate the characteristics of the recent economic growth and the implementation of SLCP in Yulin City. Third, we make three types of comparison as follows in order to make out the impact of SLCP in the village level (Fig. 1).

a) Comparison between the basic information of the households which have been participating in SLCP (SLCP participants) and that of the households which have not (non-participants)

b) Comparison between the income of households in 2000 (before the start of SLCP), in 2004 (after the implementation of SLCP)

c) Comparison between the attitude for their future prospects of the SLCP participants and that of nonparticipants

Finally we discussed the recent transformation of farmers' economic activities and concluded by investigating a way in which SLCP affected economic activity in rural areas and demonstrate the correlation between the implementation of SLCP and the economic growth in Yulin City in order to explore a method of SLCP and its sustainability.

\section{THE SLOPING LAND CONVERSION PROGRAM}

\section{General description of SLCP}

SLCP, called Tui Geng Huan Lin in Chinese, aims not only to improve watershed conditions and conserve natural resources, but also to promote rural development by providing subsidies for households who have lost their farmland. SLCP is carried out by the households who have made a contract with the County Forest Bureau or Town Government. As shown in Box 1, the program targets three types of farmlands and devastated lands and attempts to convert them into forest or grass field through the planting. Three kinds of subsidies are available to households who have converted their farmland: cash, food, and seedling. The types and amount of the subsidiaries depend upon the area of converted farmland (Table 1). Besides their own farmland, the contractors are responsible also for planting trees or grasses in the devastated land around their villages.

Converted forest/grass land is classified into two types according to the degree of importance in terms of conservation: ecological forest/grass land and economic forest/grass land. Ecological forest refers to an area where soil erosion and desertification are severe, particularly the banks of a river, a dam or a lake. Economic forest refers to a forest where farmers can earn income from timber and non-timber forest products, e.g. fruits, mushrooms. According to the SLCP regulations, farmers would receive subsidies for eight years in case of ecological forest, and for five years in case of economic forest. The Forest Bureau has determined that the proportion of ecological forest and economic forest should be $80 / 20$ percent in every administrative unit (State Forest Administration, 2002). In both types of forests, land ownership is guaranteed during the contract period, and the ownership of planted trees/grasses also belongs to the households who have land ownership. It is prohibited to cut down planted trees during the period of compensation.

\section{Box 1. Types of land targeted by SLCP.}

a. Farmland where soil erosion is severe (mainly the farmland with a slope of more than 25 degrees)

b. Farmland where desertification or alkalinity is severe

c. Farmland located in an ecologically important area, where the capacity of farming production is low and unstable

d. Devastated land where soil erosion is severe

Table 1. Total amount of subsidies: cash, food and seedlings.

\begin{tabular}{lccc}
\hline & Cash (RMB) & Food (kg) & Seedlings (RMB) \\
\hline Farmland along the Yellow River & 300 & 2250 & 750 \\
Farmland along the Yangtze River & 300 & 1500 & 750 \\
Devastated Land & - & - & 750 \\
\hline
\end{tabular}

Source: SFA 2002. RMB = RenMinBi = yuan. 
Design of the program and state financial expenditure associated with SLCP

During 2001-2010, the period of SLCP, a total of 32 million ha of land are to be converted to forest/grass lands. The total area of farmland subject to conversion, 14.67 million he amounts to 13 percent of the whole farmland area in China. At the completion of SLCP, 75 percent of the sloping farmland along the upper stream of the Yangtze River and the Yellow River will be converted. 46 percent of farmland that is currently decertified will be also transformed into forests or grassland. By the end of 2004, SLCP has been in effect in more than 2,000 counties across 25 out of the country's 31 provinces, autonomous regions, and municipalities (Fig. 2). It has enrolled some 15 million farmers (Xu et al. 2004). 6.1 million ha of farmland and 9.7 million ha of devastated land have already undergone plantation (Table 2).

The Central Government of China is planning to spend 337 billion RMB (RenMinBi = yuan) in order to accomplish the goals of SLCP. By the end of 2003, RMB

Table 2. Areas where SLCP was planned and implemented.

\begin{tabular}{|c|c|c|c|c|c|c|c|}
\hline \multirow{2}{*}{ Year } & \multirow{2}{*}{ Province } & \multirow{2}{*}{ County } & \multicolumn{2}{|c|}{ Farmland } & \multicolumn{2}{|c|}{ Devastated Land } & \multirow{2}{*}{ Total } \\
\hline & & & Plan & Implemented & Plan & Implemented & \\
\hline 1999 & 3 & N.A. & 381 & 397 & 66 & 70 & 467 \\
\hline 2000 & 17 & 188 & 377 & 428 & 468 & 478 & 906 \\
\hline 2001 & 20 & 224 & 356 & 420 & 492 & 563 & 983 \\
\hline 2002 & 25 & 1,580 & 2,267 & 1,975 & 2,662 & 2,157 & 4,132 \\
\hline 2003 & N.A. & N.A. & 2,640 & 2,233 & 3,333 & 3,333 & 5,567 \\
\hline 2004 & 23 & N.A. & 667 & 659 & 3,331 & 3,078 & 3,737 \\
\hline Total & & & & 6,113 & & 9,679 & 15,792 \\
\hline Planed Area & & & & 14,667 & & 17,333 & 32,000 \\
\hline
\end{tabular}

Source: China Green Post, 2003; Lou, 2004. Unit = 1,000 ha.

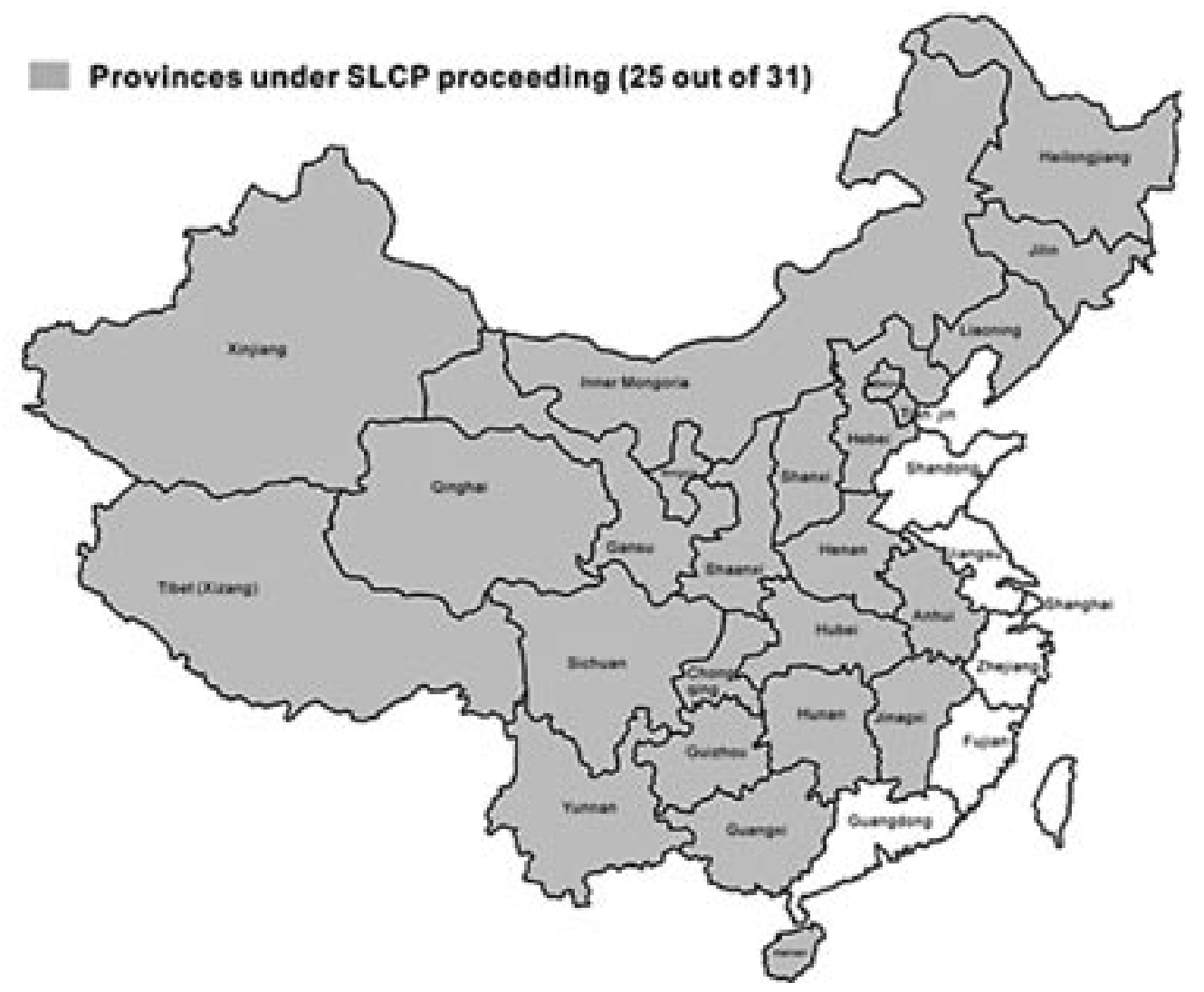

Fig. 2. Provinces in China where SLCP was carried out. 


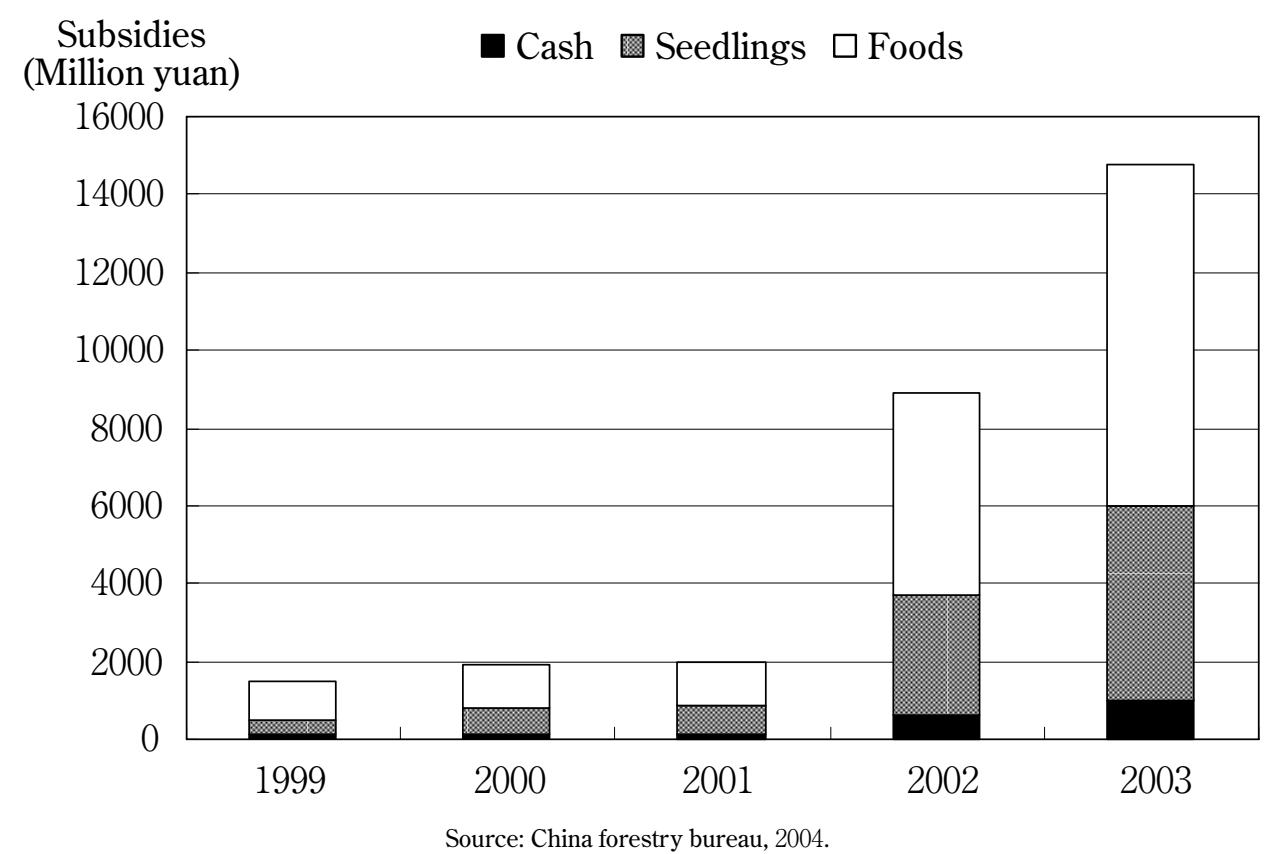

Fig. 3. Breakdown of the investment in subsidies.

39,454 million was appropriated for SLCP. Of this total amount, 36,642 million RMB was invested by the Central Government of China. In 2003, 22,599 million RMB, the investment for SLCP, occupied 66 percent of the total national investment in forestry, and 14,750 million RMB was spent for SLCP as subsidies for the contracting households (Fig. 3).

Besides its sheer size, SLCP differs from a typical program of water and soil conservation and even from other forestry plans in China for two major reasons. First, the Central Government has stated that the program aims not only to conserve soil and water in China's ecologically fragile areas, but also to restructure the rural economy, so that the participating farmers can gradually shift into more environmentally and economically sustainable activities, such as livestock breeding and off-farm work (State Forest Administration, 2002). Hence the program is unique for its integration of both environmental and poverty reduction goals. Second, the program directly engages millions of rural households as the core agents of the project implementation. The government has estimated that upon completion the SLCP will affect 40-60 million rural households (Xu et al. 2004).

\section{RESULTS}

\section{Regioal level}

\section{General conditions of the region}

Yulin City is the prefecture-level city located in the northern part of Shaanxi Province, which is surrounded by Shaanxi Province, Inner Mongoria Autonomous Region, and Ningxia Autonomous Region (Fig. 4). The area of Yulin consists of 12 counties, and can geographically be divided into two parts through rainfall and topography. The Northern area of Yulin is the area where annual precipitation is less than $400 \mathrm{~mm}$ per year. The Southern area of Yulin, where annual precipitation is around $450 \mathrm{~mm}$ per year, is located in the northern part of Loess Plateau spreading out in northeast of China.

According to the census of 1999, Yulin city has a population of 3.2 million of which 85 percent reside in rural area (Table 3). Northern Yulin has a low population density and a large city population. With an annual rainfall below $400 \mathrm{~mm}$, most of the land in Northern Yulin has been undergoing desertification. In order to compensate the lack of precipitation, irrigation systems have developed in the lowlands along the river. Stock farming has also prospered in rural areas. Northern Yulin is rich in mineral resources such as coal, crude oil and natural gas. On the other hand, Southern Yulin is characterized by high population density with a large number of rural residents. In contrast to the northern area, most area of Southern Yulin receives rainfall that exceeds $400 \mathrm{~mm}$ per annum. This makes rain-fed cultivation possible in the region. For more details in the characteristics, see Table 3. 


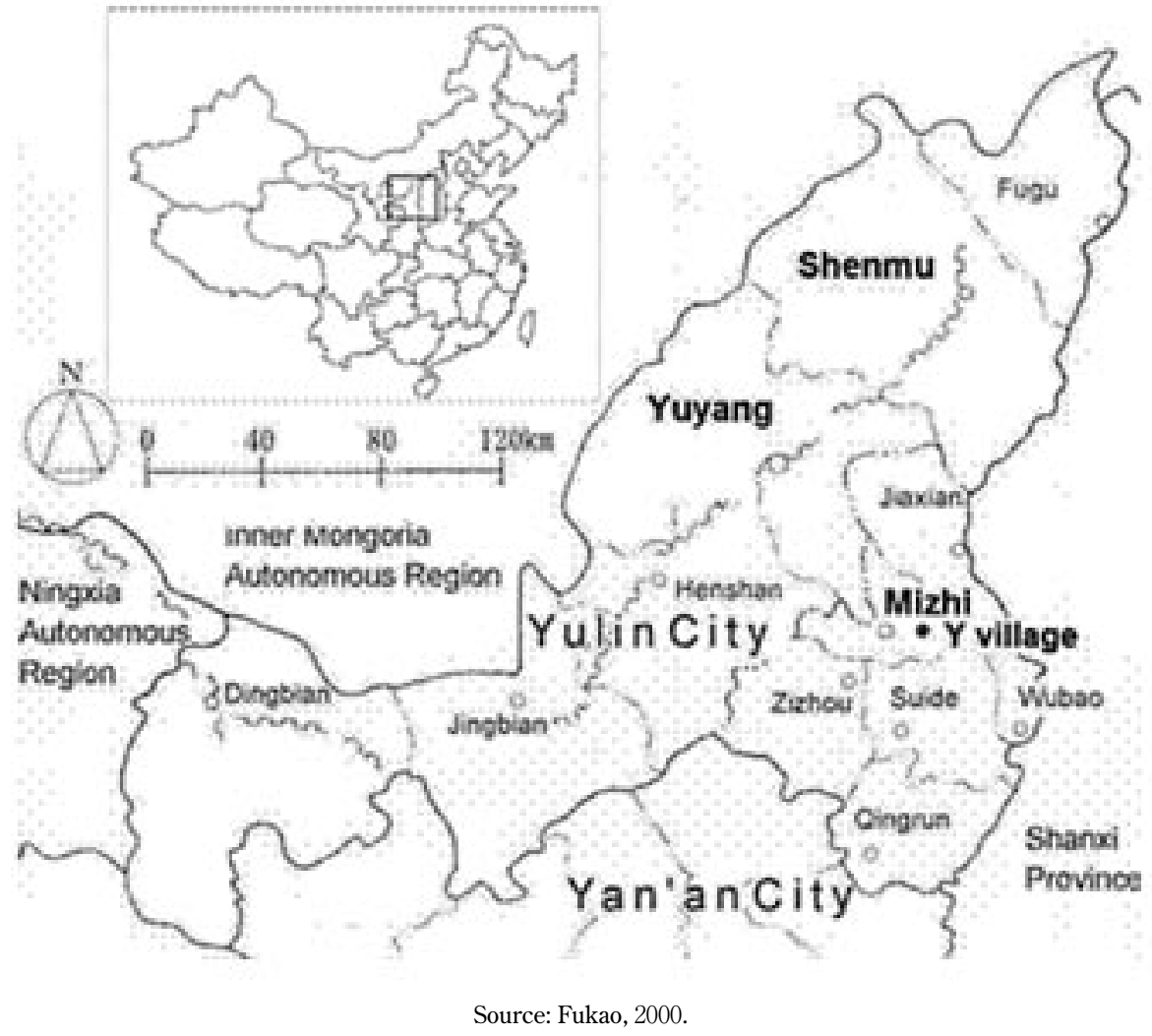

Fig. 4. Map of Yulin and Mizhi county.

Table 3. General socio-economical conditions in Yulin City.

\begin{tabular}{|c|c|c|c|c|c|c|c|}
\hline Part & County & $\begin{array}{l}\text { Population } \\
\quad(1000)\end{array}$ & $\begin{array}{c}\text { Population in } \\
\text { urban area } \\
\left(\mathrm{km}^{2}\right)\end{array}$ & $\begin{array}{c}\text { Population } \\
\text { in rural Area } \\
\left(\mathrm{km}^{2}\right)\end{array}$ & $\begin{array}{l}\text { Ratio of urban } \\
\text { population (\%) }\end{array}$ & Area $\left(\mathrm{km}^{2}\right)$ & $\begin{array}{c}\text { Density } \\
\text { (Person } / \mathrm{km})\end{array}$ \\
\hline \multirow{6}{*}{$\begin{array}{l}\text { Northern } \\
\text { Yulin }\end{array}$} & Yuyang & 428 & 130 & 298 & 30.4 & 7,035 & 60.9 \\
\hline & Shenmu & 361 & 87 & 274 & 24.1 & 7,635 & 47.3 \\
\hline & Fugu & 216 & 36 & 179 & 16.8 & 3,212 & 67.2 \\
\hline & Henshan & 324 & 28 & 297 & 8.5 & 4,081 & 79.4 \\
\hline & Jingbian & 274 & 31 & 242 & 11.5 & 5,088 & 53.9 \\
\hline & Dingbian & 300 & 35 & 266 & 11.6 & 6,920 & 43.4 \\
\hline \multirow{7}{*}{$\begin{array}{l}\text { Southern } \\
\text { Yulin }\end{array}$} & Suide & 345 & 45 & 300 & 13.1 & 1,878 & 183.7 \\
\hline & Mizhi & 207 & 24 & 183 & 11.6 & 1,212 & 171.0 \\
\hline & Jiaxian & 246 & 20 & 226 & 8.1 & 2,144 & 114.8 \\
\hline & Wubao & 77 & 12 & 65 & 15.0 & 428 & 179.4 \\
\hline & Qingjian & 208 & 20 & 188 & 9.4 & 1,881 & 110.4 \\
\hline & Zizhou & 309 & 25 & 284 & 8.0 & 2,042 & 151.3 \\
\hline & Total Yulin & 3296 & 493 & 2804 & 14.9 & 43,556 & 75.7 \\
\hline
\end{tabular}

Source: National Bureau of Statistics of China, 2000. 


\section{Economic growth in Yulin}

Let us compare economic growth in three counties representing the northern and southern areas. We choose Yuyang Ward and Shenmu County for the sample cases of the north because they closely follow the general trend of the populace distribution in the region, characterized by a low population density and a high ratio of city to rural inhabitants. For the south, we pick up Mizhi County for the same reason. Fig. 5 shows the GDP growth in the counties of northern Yulin (Shenmu, Yuyang) and southern Yulin (Mizhi) in the 1990s. In 1990, the GDP per capita was 790 RMB in Yuyang, 831 RMB in Shenmu and $493 \mathrm{RMB}$ in Mizhi. As the figure shows, GDP per capita jumped from 790 to 3,216 RMB in Yuyang, 831 to 4,755 RMB in Shenmu, and 493 to 816 RMB in Mizhi by 2000. The gap in GDP per capita between Shenmu and Mizhi has widened from 1.69 to 5.84 times. This is part of the tendency in Yulin where the difference between rich and poor counties has been diverging through the 1990s. Fig. 6 and Table 4 both show the details of economic growth in the three counties. It is clear from the above data that the increase of the agricultural GDP contributed

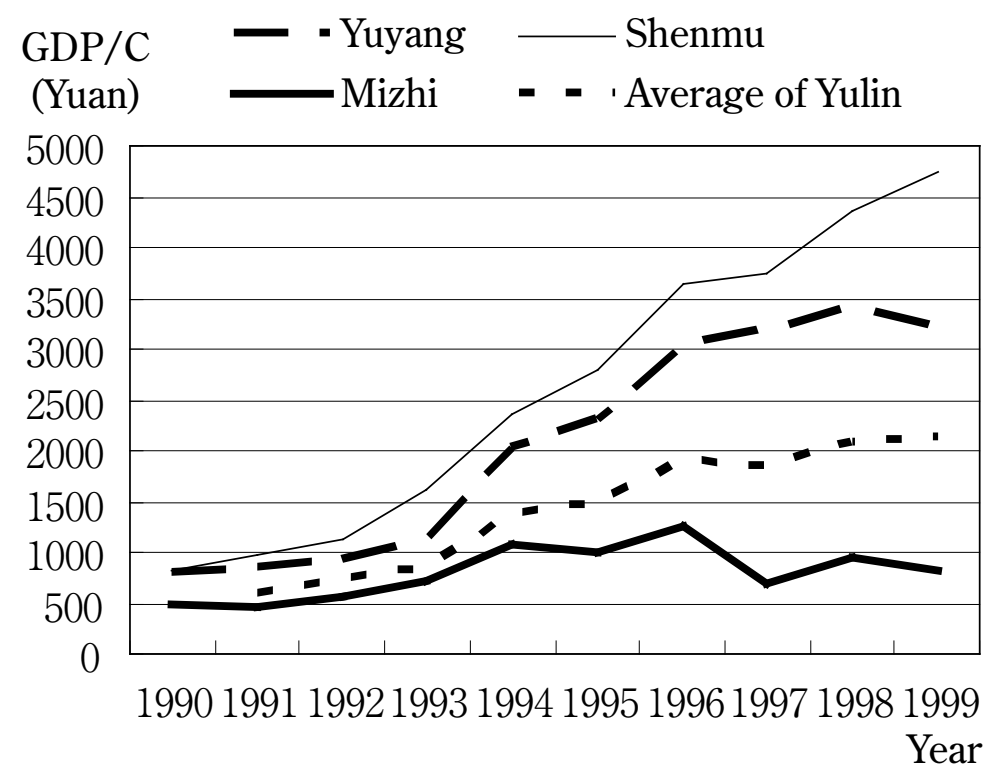

Source: National Bureau of Statistics of China, 1989-2004.

Fig. 5. GDP growths in each area of Yulin.

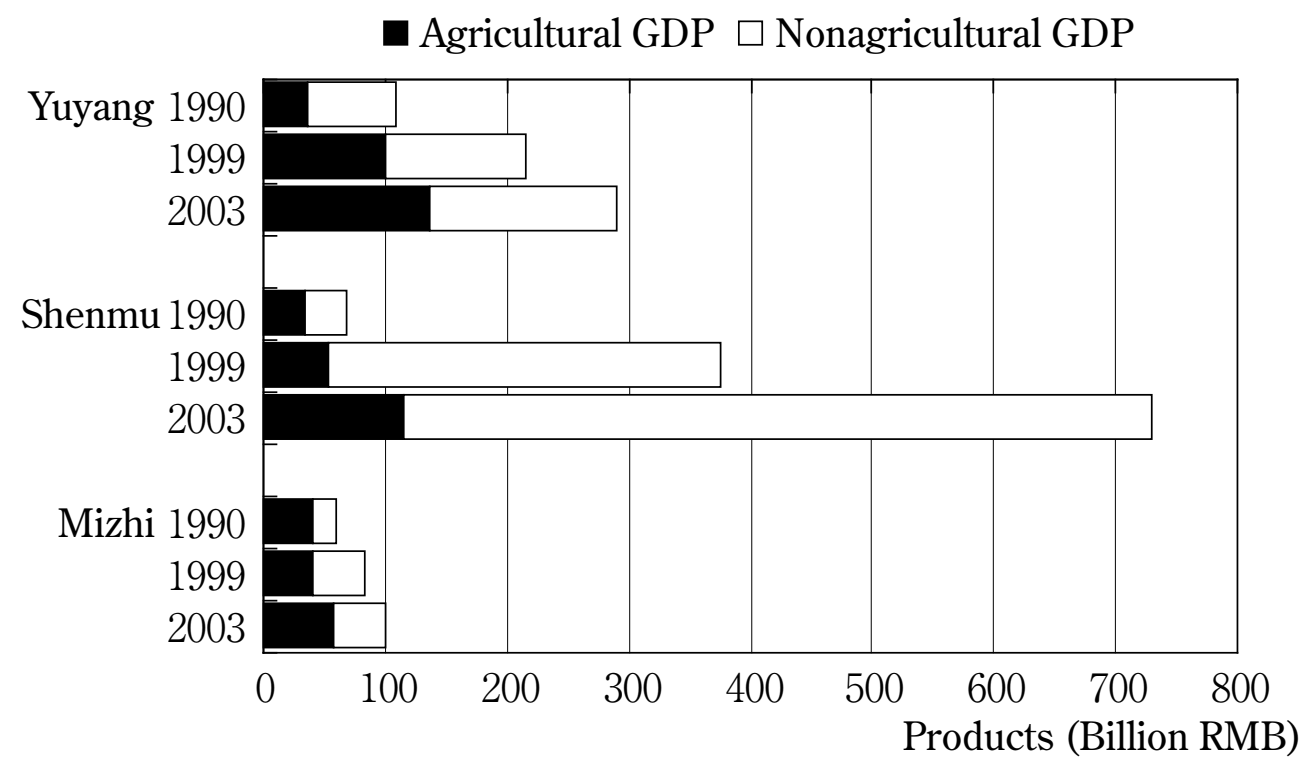

Source: National Bureau of Statistics of China, 1989-2004.

Fig. 6. GDP growths in each county of Yulin. 
Table 4. Breakdown of GDP growths in each county of Yulin (1990-2003).

\begin{tabular}{llrccc}
\hline County & Year & Agricultural GDP & Nonagricultural GDP & Total GDP & Ratio of change \\
\hline \multirow{4}{*}{ Yuyang } & 1990 & $369(34 \%)$ & $722(66 \%)$ & 1,092 & 1.96 \\
& 1999 & $1,008(47 \%)$ & $1,137(53 \%)$ & 2,145 & 1.35 \\
\hline \multirow{5}{*}{ Shenmu } & 2003 & $1,375(47 \%)$ & $1,522(53 \%)$ & 2,897 & 5.49 \\
& 1990 & $340(50 \%)$ & $345(50 \%)$ & 684 & 1.94 \\
\hline \multirow{4}{*}{ Mizhi } & 1999 & $541(14 \%)$ & $3,217(86 \%)$ & 3,758 & 1.41 \\
& 2003 & $1,153(16 \%)$ & $6,137(84 \%)$ & 591 & 1.19 \\
\hline
\end{tabular}

Source: National Bureau of Statistics of China, 1989-2004. GDP = 1RMB per capita.

to the economic development of Yuyang. In Shenmu, the increase of the nonagricultural GDP also accounted for its growth. In contrast, in Mizhi, although agricultural GDP was at its highest among the three counties in 1990, it had increased only by 40 percent from 1990 to 1999. As a consequence of, these economic changes, this county was still ranked at the lowest of the three counties in terms of both agricultural and nonagricultural GDPs in 2003.
This situation may invite a question: what was the trigger for economic growth in northern Yulin? Fig. 7 illustrates the amount of national investment in Yulin economy. As this bar chart indicates, national investment has shown a sharp increase since 1995. There is also another upturn from 2000 to 2003. For our understanding of the reason behind this development, Table 5 would be helpful. This table demonstrates the expansion of natural

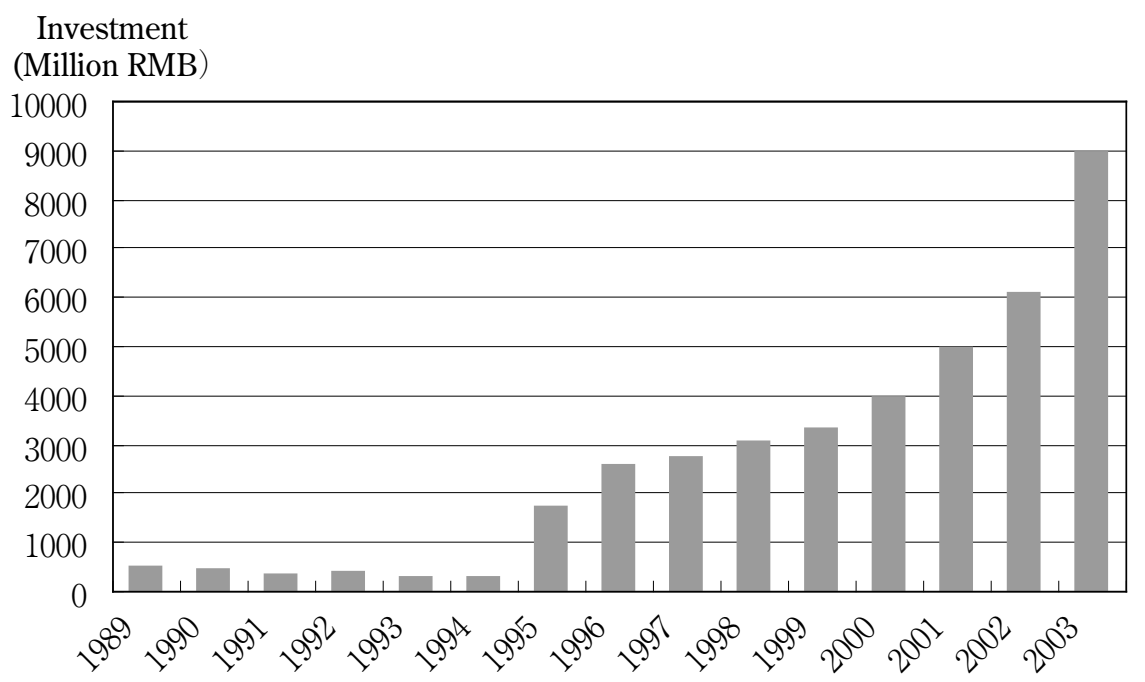

Source: National Bureau of Statistics of China, 1989-2004.

Fig. 7. National investment in Yulin city.

Table 5. Development of natural resources in Yulin city.

\begin{tabular}{cccc}
\hline Year & Coal $(1000 \mathrm{t})$ & Crude oil $(1000 \mathrm{t})$ & Natural gas $\left(\right.$ million $\left.\mathrm{m}^{3}\right)$ \\
\hline 1999 & 6,630 & 520 & 1,257 \\
2000 & 16,400 & 890 & 2,110 \\
2001 & 40,000 & 2,520 & 3,440 \\
2002 & 57,120 & 3,300 & 4,040 \\
2003 & 71,680 & 2,800 & 4,950 \\
\hline
\end{tabular}


resource production in Yulin. The output of coal, crude oil and natural gas has multiplied in the last five years. Judging from the above data and the recent economic growth of China as a whole, we can speculate about the mechanism of economic growth in Yulin as follows. The government-led investment which centered in natural resources started in the mid of 1990s in order to meet the increased demand of energy in China. In addition, the "Go West" campaign since 1999 has pumped more investment into Yulin. As a result, the investment in natural resources brought economic prosperity to northern Yulin.

\section{Implementation of SLCP in Yulin}

In Yulin City, SLCP began in 1999. According to the SLCP regulation defined by the City, Yulin Forest Bureau has categorized three types of land and designated them as subject to SLCP (Box 2). Because more than half of the farmland in Yulin are under the threat of desertification or located on slopes, the City government

\section{Box 2. SLCP target lands in Yulin.}

a. More than six degrees sloping farmland

b. Farmland under desertification

c. Devastated land designed a plan that SLCP should be applied to 68 percent of the farmland in the entire Yulin City. As a result, the farmland designated as subject to SLCP in Mizhi County accounted for as much as 79 percent of the total cultivated land in the county (Table 6). It is expected that roughly two million farmers in Yulin will lose their farmland to a certain extent upon the completion of SLCP.

By May 2003, 1.5 million ha of farmland and 1.8 million ha of devastated land had already been converted to forests or grassland in Yulin City (Table 7). The space of the converted farmland is 13 percent of the entire farmland in Yulin. We may safely estimate that the implementation of SLCP has already been affecting the agricultural livelihoods of a certain proportion of farmers in Yulin. In the next section, we will discuss the process of implementing SLCP and show how this process has been influencing the way in which households develop their strategy of livelihood at the village level.

\section{Village level \\ General Condition in $Y$ village}

$\mathrm{Y}$ village is a small village on the Loess Plateau, located $20 \mathrm{~km}$ southeast of central Mizhi. A small stream named Xiaohe runs through the village and flows into a canyon where people live in a house called Yaotong, a type of residence common in the Loess Plateau region. Xiaohe empties into Wudinghe River which runs from north to

Table 6. SLCP planning in Yulin City.

\begin{tabular}{ccccc}
\hline \multirow{2}{*}{ Farmland } & \multicolumn{2}{c}{ Yulin } & \multicolumn{2}{c}{ Mizhi } \\
\cline { 2 - 5 } & Farmland & SLCP Area & Farmland & SLCP Area \\
\hline 25deg $>$ & 330.6 & 320.1 & 14.0 & 14.0 \\
$15-25 \mathrm{deg}$ & 283.5 & 246.7 & 29.3 & 29.3 \\
$6-15 \mathrm{deg}$ & 204 & 159.1 & 5.3 & 5.3 \\
Desertification & 116.7 & 74.1 & 0.0 & 0.0 \\
Total area of SLCP target & 934.8 & 800.0 & 48.7 & 48.7 \\
\hline Total area of farmland & $1,168.0$ & 800 & 61.9 & 48.7 \\
\hline
\end{tabular}

Source: The document from the SLCP department of Yulin Forest Bureau. Unit = 1,000 ha.

Table 7. Actual implementation area of SLCP in Yulin City.

\begin{tabular}{crrrrrrr}
\hline & \multirow{2}{*}{ Total } & \multicolumn{3}{c}{ Farmland (1,000 ha) } & \multicolumn{3}{c}{ Devastated Land (1,000 ha) } \\
\cline { 3 - 7 } & & Forest & Grass & Total & Forest & Grass & Total \\
\hline 1999 & 48.41 & 18.70 & 5.83 & 24.53 & 16.26 & 7.62 & 23.88 \\
2000 & 8.47 & 6.47 & 1.20 & 7.67 & 0.64 & 0.16 & 0.80 \\
2001 & 11.40 & 3.27 & 1.40 & 4.67 & 5.39 & 1.35 & 6.73 \\
2002 & N.A. & N.A. & N.A. & 53.33 & N.A. & N.A. & N.A. \\
\hline By May 2003 & 334.81 & N.A. & N.A. & 153.53 & N.A. & N.A. & 181.28 \\
\hline
\end{tabular}

Source: The document from the SLCP department of Yulin Forest Bureau. 
south in Yulin City and eventually enters the Yellow River. The height of the canyon is above 200 meters, and most of the sloping area of the canyon is thoroughly cultivated from bottom to top. The Loess Plateau is notable for its soil. The particles of the soil are usually those of silt loam which is minuter than normal soil. Therefore, land without vegetation in the plateau is substantially vulnerable to soil erosion from rain and wind. In $\mathrm{Y}$ Village, most of the land is undergoing topsoil erosion and gully erosion (Picture 1).

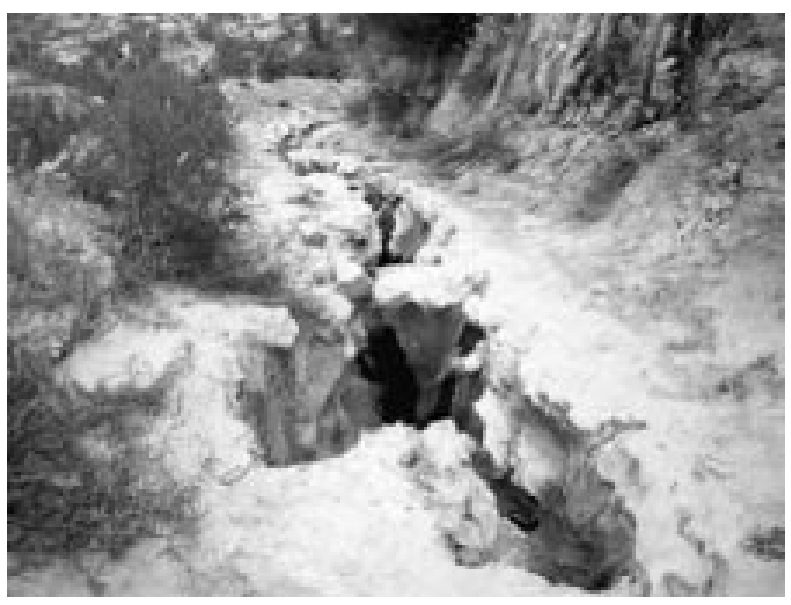

Picture 1. Mountain path with soil erosion in $\mathrm{Y}$ village.

Table 8. Land in Y village.

\begin{tabular}{ccc}
\hline & Land area & Farmland area \\
\hline Area & 375.00 & 166.00 \\
Area/Family & 1.45 & 0.64 \\
Area/capita & 0.33 & 0.14 \\
\hline
\end{tabular}

Source: Fukao, 2000; field survey in 2004.

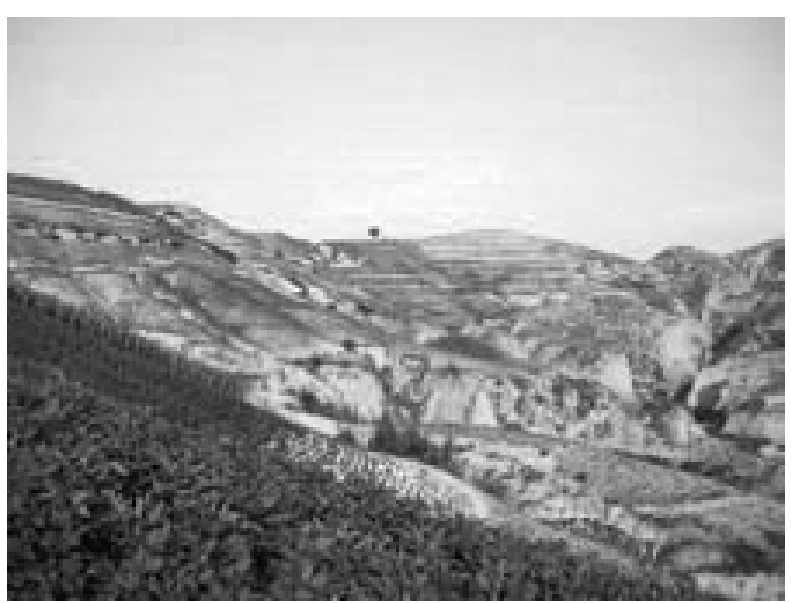

Picture 2. Sloping farmland in $\mathrm{Y}$ village.
According to a national census in 2000, 1,153 people and 259 households are living at the Y village. Of 375 ha of the total area of the village, 166 ha are categorized as farmland (Table 8). More than 60 percent of the farmland is located on sloping terrain, about 30 percent is the terraced field constructed in the 1960-70s, and the remaining 10 percent is flat farmland (Picture 2). Almost all households practice farming and develop crops such as corn, potato, soybean and foxtail millet. The average farmland area is 0.64 ha per household. Every household has four or five small lots because the farmland was divided up evenly among village households at the time of the land reform in the 1980s. Nonagricultural works are limited to such jobs as a shopkeeper (three households), a crop broker (one) and a taxicab driver (three).

\section{Implementation of SLCP in the village}

According to an interview with an official from the Mizhi Forestry Bureau, the SLCP calendar can be described as below (Box 3). In Y village, SLCP started in 2002. By August 2004, about 70 of 259 households had participated in SLCP. 40 of 166 ha farmland has been already converted into forests or grass fields. More farmland is expected to be converted as the Mizhi Forest Bureau attempts to maintain the pace of the implementation of SLCP at each village of the county.

Box 3. The calendar of SLCP in Y village.

February: Annual responsible area of each town is decided by the Mizhi County Forest Bureau.

Top of March: Town government decides responsible area of each village.

Middle of March: Responsible area is distributed to farmers by the lead of the Villagers' Committee.

End of March-April: Tree and grass is planted by farmers

August-October: Planted tree and grass are investigated by the Mizhi County Forest Bureau

One of the staff of the Village Committee explained that they have not completely distributed subsidies in the form of cash, food, and seedlings. All 14 SLCP participants we interviewed claimed that they did not receive cash even after the Forestry Bureau had conducted an investigation. Five of them said that they did not receive food either. With regards to seedlings aid, the households received material in kind, not in cash. Of five 
species identified to be distributed in Y village, three are for ecological forests: Chinese arborvitae (Platyclaudus orientalis), Pea tree (Caragana psammophyla) and Chinese pine (Pinus tabulaeformis); and two for economic forests: Chinese jujube (Zizyphus jujuba) and Chinese apple (Malus pumila). When asked about the condition of vegetation, they replied that the land was covered with grass and seedlings after they stopped cultivation.

\section{Household income comparison between SLCP participants and non-participants}

In order to gain an insight in the transformation of livelihood resulted from SLCP, we analyzed the basic information regarding the extracted 27 households shown in Table 9, divided them into the SLCP participants and the non-participants, and made a comparison between them in terms of the growth in income and its sources.

Fig. 8 shows the average net income the SLCP participants and the non-participants gained in 2000. Fig. 9 indicates the average net income both of the groups earned before the introduction of SLCP (in 2000) and after (in 2004). First, let us compare the income of the
SLCP participants and that of the non-participants in 2004. As Fig. 8 demonstrates, the former earned twice as much as the latter. Although this chart shows little difference between them in the section of agricultural income, the substantial discrepancy in nonagricultural income leads to the gap in total income. Next, let us compare between before the beginning of SLCP and its afterward. Fig. 9 illustrates that the difference in total income between the SLCP participants and the non-participants has widened. Indeed, during the four years since 2000, the earning of the SLCP participants doubled. In particular, their nonagricultural income jumped from 1,448 RMB to 7,559 RMB.

Table 10 reveals why the nonagricultural income of the SLCP participants recorded such a drastic increase. It indicates the number of migrant workers in the family of the participants and non-participants. According to this table, after the launch of SLCP in Y village, the number of migrant workers in the family of SLCP participants recorded a steep rise. In fact, the income from migrant labor occupied more than 70 percent of the nonagricultural income of both participants and non-

Table 9. Basic information of the participants.

\begin{tabular}{lcccc}
\hline \multicolumn{1}{c}{ Householde } & Age of householder & Number of household & Number of child & Area of farmland (ha) \\
\hline SLCP participants $(\mathrm{n}=14)$ & 47.40 & 4.70 & 2.60 & 0.88 \\
Non participants $(\mathrm{n}=13)$ & 45.78 & 3.56 & 1.56 & 0.40 \\
\hline
\end{tabular}

Source: Field survey in 2004

- Agricultural income $\square$ Non-Agr. income $\square$ Subsidies

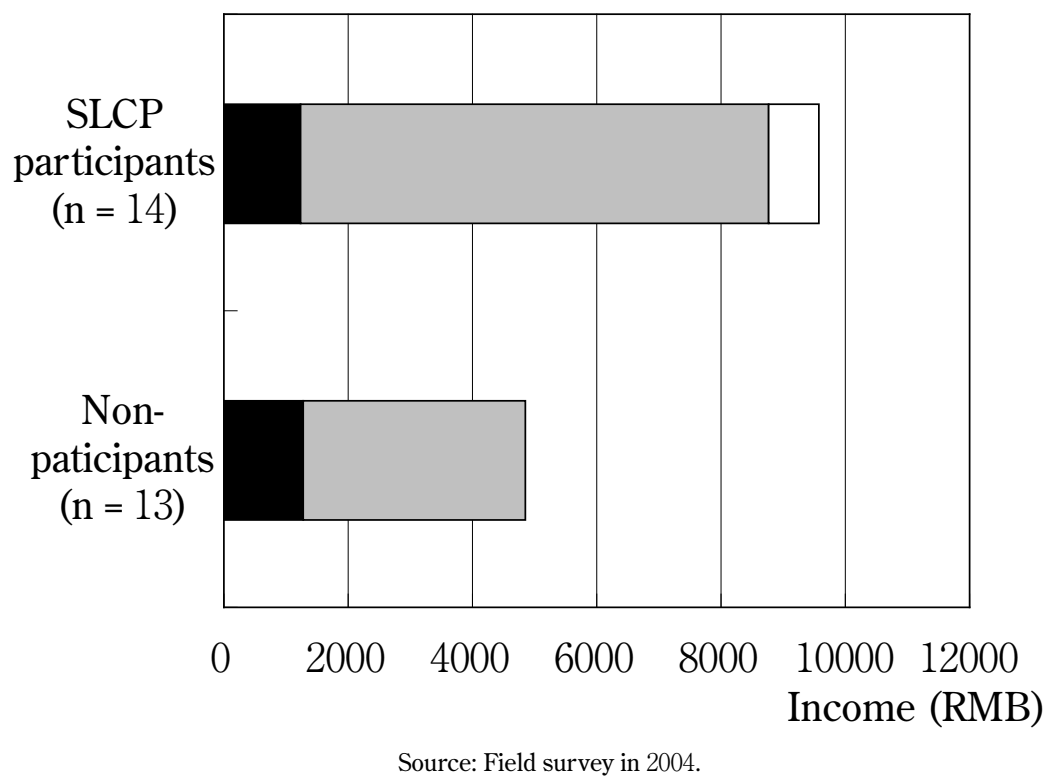

Fig. 8. Gross income of the households participating and not participating in SLCP, 2004. 
Agriculture income $\square$ Nonagriculture income $\square$ Subsidies

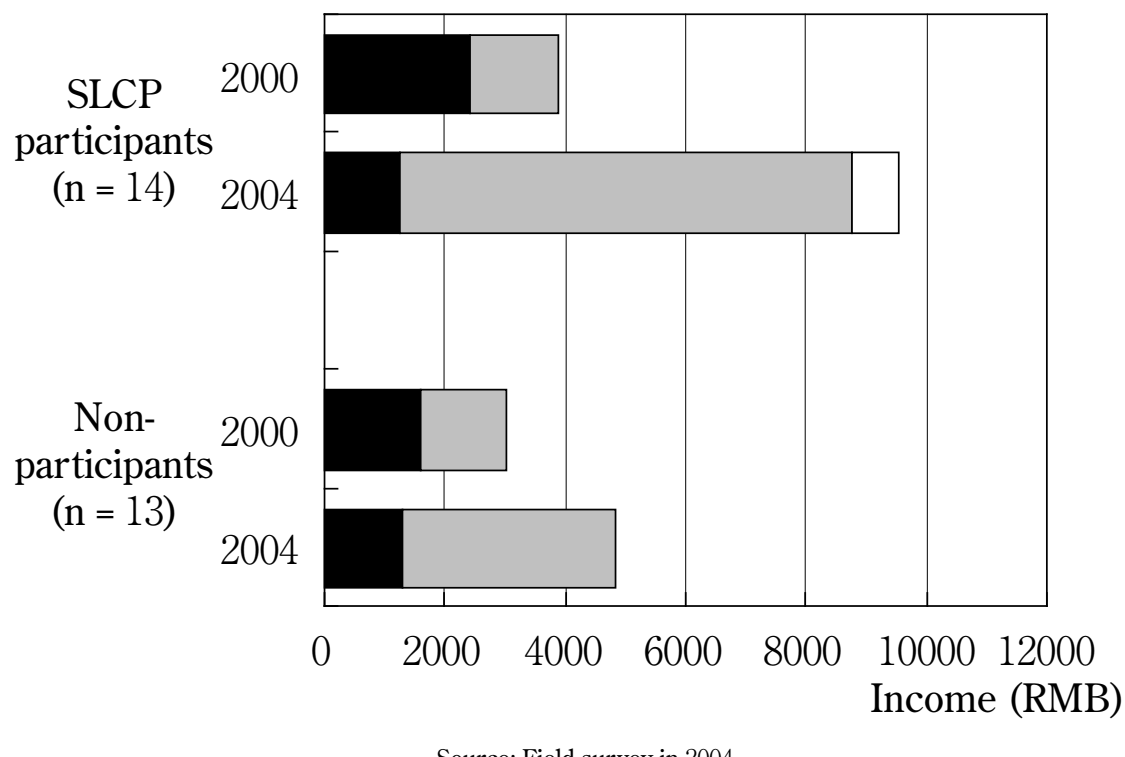

Fig. 9. Income of the households participating and not participating in SLCP, 2000 and 2004.

Table 10. The first year of migrant works.

\begin{tabular}{ccc}
\hline Year & $\begin{array}{c}\text { SLCP } \\
\text { participants }\end{array}$ & non-participants \\
\hline Before 1998 & 2 & 4 \\
1998 & 1 & 1 \\
1999 & 2 & 0 \\
2000 & 0 & 1 \\
2001 & 0 & 2 \\
2002 & 5 & 1 \\
2003 & 12 & 1 \\
2004 & 2 & 0 \\
\hline Total & 24 & 10 \\
\hline
\end{tabular}

Unit: Number of family member

Source: Field survey in 2004.

participants in 2004. Next, Table 11 illustrates what type of labor the villagers engaged in for their first migrant works. Here we can see that, before the beginning of SLCP, they worked mostly as manual labor in the sectors such as mining and construction. After SLCP started, however, the types of migrant works have diversified. Another notable aspect is that more than 50 percent of the villagers work in the district of Yulin City as migrant workers. The increasing number of opportunities and the diversification of the types of migrant works have contributed to the rise in the gap between the income of the participants and that of the non-participants during the four years since the inception of SLCP.
Table 11. The variety of migrant workers.

\begin{tabular}{ccc}
\hline Year & Manual labor & Others \\
\hline Before 1998 & 5 & 1 \\
1998 & 0 & 2 \\
1999 & 1 & 1 \\
2000 & 1 & 0 \\
2001 & 2 & 0 \\
2002 & 3 & 3 \\
2003 & 5 & 8 \\
2004 & 1 & 1 \\
\hline Total & 18 & 16 \\
\hline
\end{tabular}

Unit: Number of family member Source: Field survey in 2004.

\section{Comparison of the attitude and strategy for their future}

As a next step, we asked the participants and nonparticipants the following three questions in order to understand their attitude and strategy toward livelihood, migration, and future land prospects. The first question is about their own prediction about their livelihood in the future (Fig. 10). When we asked what sort of the means of livelihood they would be dependent on in the future, the SLCP participants were most likely to mention migrant labor while this option comes in the second place among the non-participants. The most preferred method among them was land cultivation. On the other hand, only 
$\square$ SLCP paticipants ( $\mathrm{n}=14) \quad \square$ Non-participants ( $=13$ )

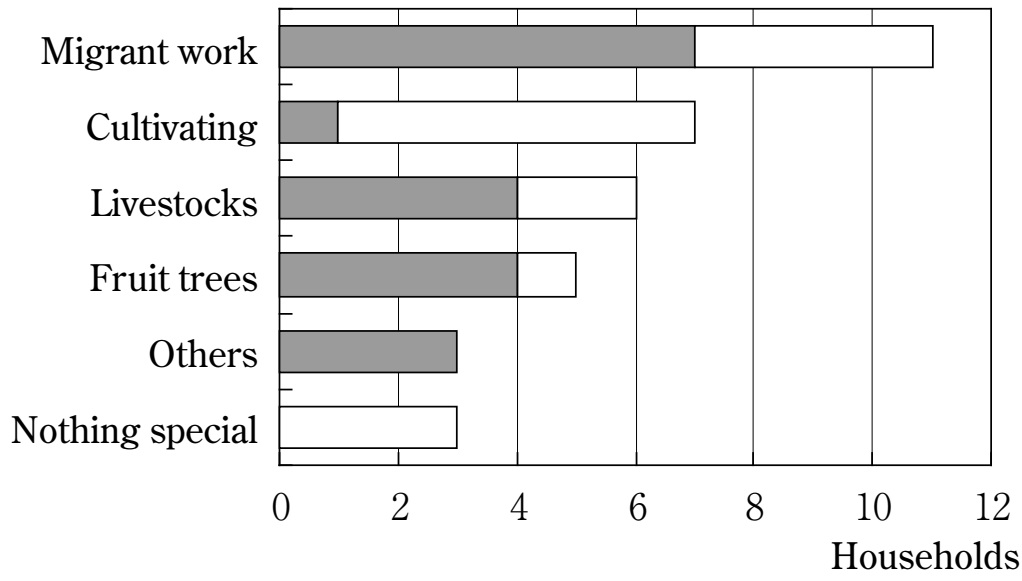

Source: Field survey in 2004.

Fig. 10. The attitude toward livelihood strategy of the participants and non- participants.

want $\square$ If there is a job $\square$ not very $\square$ do not want

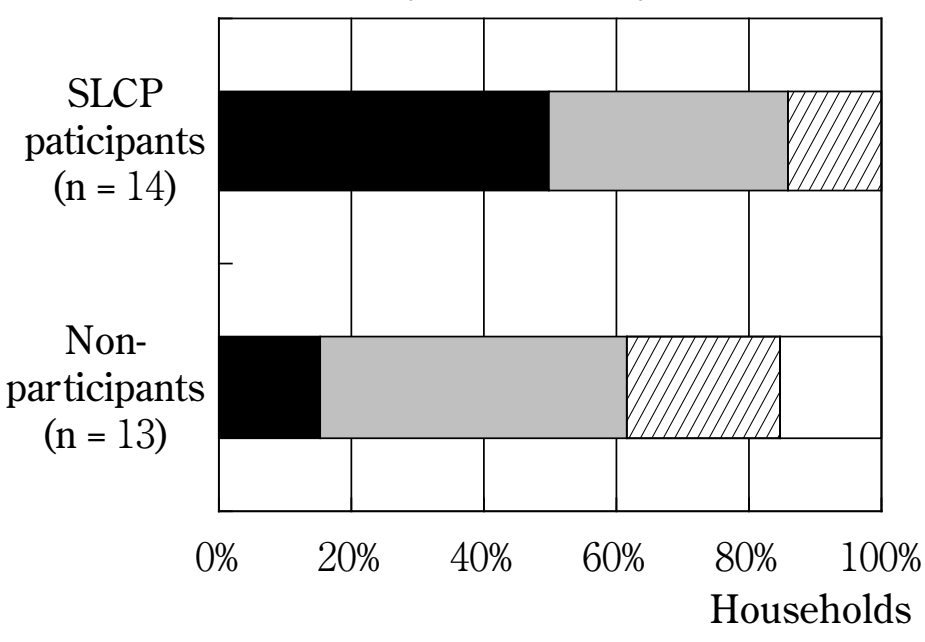

Source: Field survey in 2004

Fig. 11. The attitude toward migration of participants and non-participants.

- Absolutely no need $\square$ Mostly no need $\square$ Mostly need $\square$ All need

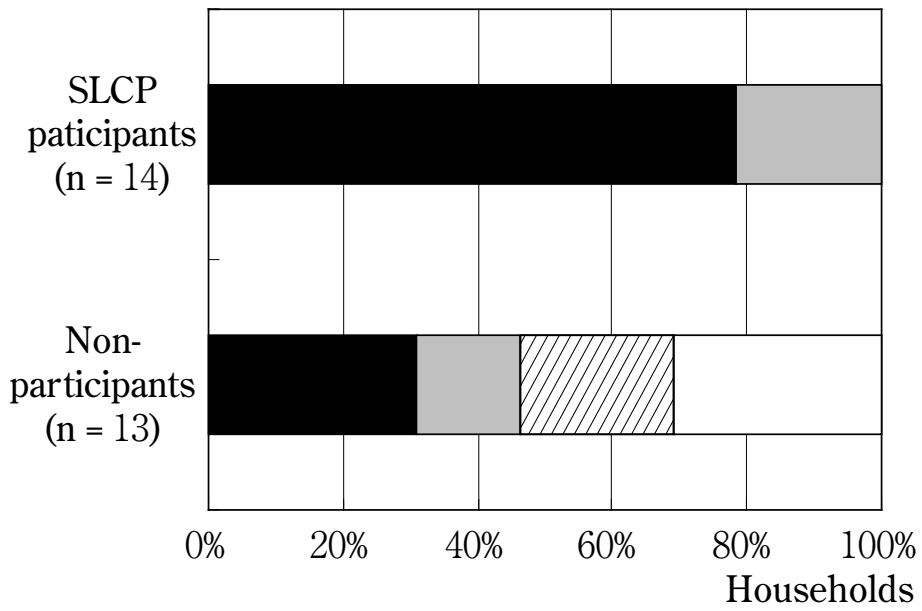

Source: Field survey in 2004

Fig. 12. The attitude toward land ownership of participants and non-participants. 
one SLCP participant mentioned the option of cultivation.

The second question we asked was whether they would like to migrate in the future (Fig. 11). In a reply, more than 80 percent of the SLCP participants and more than 50 percent of the non-participants answered "yes" or "yes if there is a job", only 2 households of the nonparticipants answered "no".

The final question was whether they would still need their cultivated land if they migrate to another place. Their answers underscore an even clearer discrepancy between the SLCP participants and the non-participants. Although all SLCP participants replied "absolutely no need" or "mostly no need", more than half of the nonparticipants said "mostly no need" or "need" (Fig. 12). This difference can be understood as an indicator of the transformation of the farmers' livelihoods under SLCP. We find that people who have an opportunity to work as migrant workers have a tendency to pursue the option of migration and are willing to abandon their land ownership. Indeed, we found that several lots of land had been abandoned due to the migration of farmers, which bears out our hypothesis.

\section{DISCUSSION AND CONCLUSION}

Overall, SLCP is an effective initiation to increase and diversify nonagricultural income. As our case study of $Y$ village has shown, this was a particularly effective strategy for the participants. Furthermore, we may be able to hypothesize the model of the transformation in the village farmer's methods of income as follows: after SLCP was introduced in the village, the participants could divert more time from land cultivation. At the same time, the government-led investment in the natural resources sector also started in the mid-1990s in order to meet the increased demand of energy in China. The "Go West" campaign, inaugurated in 1999, accelerated the pace of investment in Yulin. Accordingly, the consequent economic growth created a large amount of employment opportunities in the regional of Yulin City. The economic development in Yulin and the implementation of SLCP together had a great impact on the livelihood of the rural society.

Our case study also enables us to speculate about a possible correlation between the economic growth and the success of SLCP. As long as the regional economy booms, SLCP participants can diversify their livelihood and therefore environmental conditions will improve in the land with enough temperature and annual rainfall for vegetation. There are three main reasons why we argue so. First, the SLCP participants would likely take an advantage of SLCP to diversify their livelihood. As this study has demonstrated, the longterm economic development at the regional level yields a new opportunity of employment and absorbs migrant workers who have stopped cultivating in the sloping land. Second, we have already seen that migrant workers tend to pursue the option of migration and waive their land ownership. Finally, as SLCP progresses, the pressure on cultivation decreases. If farmers' livelihood becomes sufficiently diversified and gradually independent of agricultural income, they would not start cultivating the SLCP land again after the expiration of contract and there is a possibility of natural recovery of nature, a scenario confirmed in Y village.

The above mechanism, however, would not function equally throughout China as there is an internal economic inequality in the nation, known as a double disparity between urban and rural areas and between coastal and inland regions. The difference in GDP between the richest city Shanghai and the poorest province Guizhou is now 13 times (National Bureau of Statistics of China, 2004). Moreover, there are also significant economic disparities between urban areas and rural areas inside both Shanghai and Guizhou. Considering the substantial economic disadvantage of being located in the rural inland, Yulin has been fortunate to be rich in mineral resources. Many other areas situated similarly as Yulin, however, have a more bleak economic prospect. A major key to the sustainable implementation of SLCP will be thus to fathom the SLCP's impact on underdeveloped areas, secure employment, and diversify farmers' methods of livelihood in these areas.

ACKNOWLEDGEMENTS This study was financially supported by the Grant-in-Aid for Scientific Research (A), the Japan Society for Promotion of Sciences (NO: 13372005). We would also like to express our gratitude to Dr. Fukao Yoko in Osaka University of Foreign Studies and Dr. Yasutomi Ayumu in the University of Tokyo, both of who introduced us the Y village in the winter 2003. Drs. Fukao and Yasutomi have been conducting research in Mizhi County and Y village more than ten years. We could not complete our study unless their insightful advice and warm support. We have also appreciated Mr. Hirano Yuichiro and Dr. Seki Yoshiki, for their help in correcting the references and materials. Finally, we should especially note our debt to Mr. Ye Bing in the Chinese Academy of Forestry and Mr. Zhu Xuzhou in the Yulin Forestry Bureau, who helped 
us to conduct an exciting field research in the rural area of China. Last but not least, we should make a special note about the hospitality of Mr. Ma Zhihui and his wife, Ms. Chang Jufang, who welcomed us with their room and meals for the time of our research at $Y$ village where there was no restraint and hotel. Their help made our field research productive and successful.

\section{REFERENCES}

China Green Post, 2003. The report of the National Forestry Activity Congress: The Six Major Forestry Projects. (Chinese) In the China Green Post 27 September, 2003. China Green Post, Beijing, China.

China Forestry Bureau, 2004. China forestry report. 2003. (Chinese) China Forestry Publishing House. Beijing, China.

Fukao,Y. 2000. Kodokogen no mura: Mizu, tsuchi, hito no ryushutu/saisei heno kokoromi. (Japanese) In:

. The structure of contemporary China. (ed. Kojima, R.), pp. 267-310. University of Tokyo Press. Tokyo, Japan.

Grant, A. 2003. A study of the implementation of China's Sloping Land Conservation Program 'Tui Geng Huan Lin': a case study in Hanyuan County, Sichuan Province. Forests, Trees and Livelihoods, 13: 331-343. Academic Publishers. London. U.K.

Hirano, Y. 2002. On the large-scale forestation organized by the Government and the participation of local people in the People's Republic of China. (in Japanese) Research Bulletins of the Hokkaido University Forests. 59: 67-98.

Liu, D., Edmunds, D. 2003. The promises and limitations of devolution and local forest management in China. In: Local forest management: the impact of devolution policies. (eds. Edmunds, D. \& Wollenberg, E.), pp. 55-126. Earthscan Publications Ltd. London U.K.

Lou,Y. 2004. Big adjustment of SLCP. (Chinese) Caijing 101: $69-71$.

National Bureau of Statistics of China, 2004. China statistical yearbook. 2004. (Chinese) China Statistical Publisher. Beijing, China.

National Bureau of Statistics of China. 1989. Shaanxi statistical yearbook. 1989. (Chinese) China Statistical Publisher. Beijing, China.

National Bureau of Statistics of China. 1990. Shaanxi statistical yearbook. 1990. (Chinese) China Statistical Publisher. Beijing, China.

National Bureau of Statistics of China. 1991. Shaanxi statistical yearbook. 1991. (Chinese) China
Statistical Publisher. Beijing, China.

National Bureau of Statistics of China. 1992. Shaanxi statistical yearbook. 1992. (Chinese) China Statistical Publisher. Beijing, China.

National Bureau of Statistics of China. 1993. Shaanxi statistical yearbook. 1993. (Chinese) China $¥$ Statistical Publisher. Beijing, China.

National Bureau of Statistics of China. 1994. Shaanxi statistical yearbook. 1994. (Chinese) China Statistical Publisher. Beijing, China.

National Bureau of Statistics of China. 1995. Shaanxi statistical yearbook. 1995. (Chinese) China $¥$ Statistical Publisher. Beijing, China.

National Bureau of Statistics of China. 1996. Shaanxi statistical yearbook. 1996. (Chinese) China Statistical Publisher. Beijing, China.

National Bureau of Statistics of China. 1997. Shaanxi statistical yearbook. 1997. (Chinese) China Statistical Publisher. Beijing, China.

National Bureau of Statistics of China. 1998. Shaanxi statistical yearbook. 1998. (Chinese) China Statistical Publisher. Beijing, China.

National Bureau of Statistics of China. 1999. Shaanxi statistical yearbook. 1999. (Chinese) China Statistical Publisher. Beijing, China.

National Bureau of Statistics of China. 2000. Shaanxi statistical yearbook. 2000. (Chinese) China Statistical Publisher. Beijing, China.

National Bureau of Statistics of China. 2001. Shaanxi statistical yearbook. 2001. (Chinese) China Statistical Publisher. Beijing, China.

National Bureau of Statistics of China. 2002. Shaanxi statistical yearbook. 2002. (Chinese) China Statistical Publisher. Beijing, China.

National Bureau of Statistics of China. 2003. Shaanxi statistical yearbook. 2003. (Chinese) China Statistical Publisher. Beijing, China.

National Bureau of Statistics of China. 2004. Shaanxi statistical yearbook. 2004. (Chinese) China Statistical Publisher. Beijing, China.

People's Daily, 1978. Yao zai quanguo dada tichangyixia zhishu zaolin. (Chinese) January 14, 1978. People's Daily, Beijing, China.

Seki, Y. \& Xiang, H. 2003. The SLCP and local people in the poverty area in China. (Japanese) In: From destruction to regeneration of the forest in Asia. (ed. Yorimitsu. R.), pp. 149-210. Economical Review. Tokyo, Japan.

State Forest Administration, 2002. Master plan for the Sloping Land Conversion Program. China Forestry 
Publishing House. Beijing, China.

Uno, K. 2004. The economy and development in northern Shaanxi: The indication of economy of west China. (Japanese) Bunkaronshu, 25: 127-169.

WWF, 2003. Report suggests China's Grain-to-Green plan is fundamental to managing water and soil erosion. (http://www.wwfchina.org/english/loca. php?loca=159)

Xu, Z., Bennett, M.T., Tao, R., Xu, J. 2004. China's Sloping Land Conversion Program four years on: current situation pending issues. In International forest review-special issue "forestry in China-policy consumption in forestry's newest superpower", pp. 317-326. Forest Trends. Washington D.C. U.S.A. (http://www.forest-trends.org/documents/ publications/ifr_dec-2004_final.pdf)

Zuo, T. 2002. The implementation of the Sloping Land Conversion Program. (Chinese) In: Implementing the Natural Forest Conservation Program and the Sloping Land Conversion Program: Lessons and policy implications. (eds. Xu, J., Katsigiris, E. \& Schmitt, U.), China Forestry Publishing House. Beijing, China.

Received $14^{\text {th }}$ Jul. 2006

Accepted $15^{\text {th }}$ Jun. 2007 